\title{
Actual Problems of Effective Cooperation between Business and NPO as the Factor of Sustainable Development in Russia
}

\author{
Maria Basova \\ Financial University under the Government of the Russian \\ Federation \\ Moscow, Russia \\ E-mail: mashashik@mail.ru \\ Nadezhda Arkhipova \\ Russian State University for Humanities \\ Moscow, Russia \\ E-mail: 2506539@mail.ru
}

\author{
Natalia Isaichykova \\ Gomel State Technical University named after P.O. Sukhoi \\ Gomel, Republic of Belarus \\ E-mail: natalyii@mail.ru
}

\author{
Sergey Tolkachev \\ Financial University under the Government of the Russian \\ Federation \\ Moscow, Russia \\ E-mail: satolkachev@fa.ru \\ Dmitry Morkovkin \\ Financial University under the Government of the Russian \\ Federation \\ Moscow, Russia \\ E-mail: MorkovkinDE@mail.ru
}

Elena Kolosova

Plekhanov Russian University of Economics Moscow, Russia

E-mail: t-kev@mail.ru

\begin{abstract}
The paper substantiates the advantages of an effective cooperation between business and NPO and identifies main problems arising during that process. Among other problems considered there is the cause of a deficient practice of such cooperation with a lack of a continuous financing of NPO actions at the expense of commercial structures. For these problems solutions the authors suggest a series of events for risks minimizing, pertaining to the choice of a partner by commercial structures among a large number of non-profit organizations, against the lack of clear-cut criteria of NPO professionalism; for the further system development of communications and information interchange between business and NPO based on non-financial accounting; for calling business structures to NPO charity programs financing based on a maximum using of fundraising opportunities.
\end{abstract}

Keywords-business structures; non-profit organizations; NPO; shareholders; charity programs; social-partnership technology; systems of communication and information changing; social advertising; non-financial accounting; fundraising; sustainable development

\section{INTRODUCTION}

The content of the sustainable development in a wide sense is in providing the stable rise of ecological, social, and economic spaces indexes in a long perspective, starting from the micro level (company) and (district, government and social community in general) in the end.
Companies seek for the rising of informative of interested sides about all the aspects of their actions and authenticity providing, consistency and efficiency of given information. For all of these aims there is leading a preparation of the financial and non-financial accounting [1].

For business non-profit organizations (NPO) should address as one of the significant groups of stakeholders, because that sector allows to improve the social standard of living, to provide the political and social stability in the country and its sustainable development at large. What is connected to commercial structures, their effective partnership with NPO will allow them to take the professional help in charity programs realization, to enrich mutually each other by innovative technologies, strengthening their own reputation and rising their image thereby.

\section{EFFECT}

As is known, the social stability of a commercial organization is determined by the indexes of the inner (working security and staff's health. etc.) and external condition. For the last can be related the company participation in social investments (SI) in a form of financial and non-financial help through its external social programs on its presences' territories (for example, for prevention of drug addiction and social orphan hood or in a form of buying presents to boarding schools, etc.). Non-financial help can be 
expressed in organization support of a social program by transport, equipment, placement in any other material contribution. In its turn, a commercial company can buy products (subjects) from NPO for itself necessaries and use it as presents.

Besides, professional NPO can be considered as outsourcing companies too, projecting as organizers of charity stocks of business. Wherein, a company can pay all the administrative expenses of NPO, and NPO will organize the event. In these conditions NPO, which have special technologies of the working process with unprotected categories of citizens (children, hard-working teenagers, elderly people, disabled people, etc.) can render an invaluable help in the providing of the target (addressed) using the given means in minimal expenses of event's organization. For example, in the 12th of February of 2018 in Moscow Book House in the New Arbat Street will be the presentation of "The Book of Gastronomic Stories" by the collaborated literature project of the Help Hospice Fund "Faith" and the Saint-Petersburg Publishing House "Limbus Press". One hundred rubles from every sold copy will be donated to the hospice patients help.

One more example. World fund of wild nature (WWF) [2] - is the biggest and the most experienced organization of environment protection, which has the global net in more than one hundred countries in the whole world. The Fund WWF cooperates with the group of companies IKEA in a responsible forest-using promotion, cotton cultivation by safe ecological methods and a fight against climate changing. M.Video is the partner of «tiger» program of WWF.

But apart from the evident advantages of such a cooperation, problems always exist during the process. We will consider them more detailed.

In the first case it is necessary to notice that the skeptic attitude of a commercial sector to a non-profit organizations' actions does exist, misunderstandings of the importance of these cooperation relationships, firstly based on the mistrust to charity in general, and as the conclusion- an insufficient practice of a cooperation of commercial structures with NPO.

In Russia as usual large business-structures practice charity, but small companies try to think how to help themselves at first, rather than needy people. A range of Russian companies, taking partially some social government functions, consider charity as certain 'duty' and non-profit organizations actions as the 'clear fiction'.

Mistrust leads to many commercial companies not always give authentically the results of their work, don't open the whole information about their resource opportunities of giving help to NPO, masking sometimes their good actions, fearing of many underwater rocks, which can appear subsequently. For example, nowadays there is no law, which can fully free the amount, given as the donation, from taxation. Thereby, many business-structures give the addressed help to needy people by themselves, and NPO is considered as an unnecessary intermediary.

As the researches showed, nowadays $51 \%$ of businessstructures don't have any experience of the communication with NPO. NPO activity in the calling in business to charity is low and ineffective also [3]. NPO representatives complain that the dominating number of their help-inquiries, addressed to commercial companies, are being ignored and don't become the specific charity events. Only 5\% of making charity companies, show charity help based on NPO inquiries.

To change the approach, to find mutually beneficial contacts with NPO and stimulate the charity development in Russian commercial structures can help the analysis of a positive experience of non-profit organizations' actions, the opportunity to take benefit from this communication and the literate approach for the technology choice of a social investment, which have a rather wide range: from the traditional straight social investments to social partnership. In our opinion the most interesting and progressive approach is the technology of a social partnership, which is realized by a local power communication with business and non-profit organizations for partnership social-oriented projects implementation.

The distinctive feature of partnership projects became the association of efforts of leader companies of a district line for the solution of the separate taken problem. The leader companies attract NPO for projects realization of a wide range of destinations. The communication is building with big federal NPO and with district NPO (urban or regional) also, a line of the leader companies has its own corporate funds also.

Partnership projects are being realized by following destinations:

- Social and youth enterprise;

- Staff potential development, working education of the youth;

- Socializing and rising of boarding schools educated and graduated people competitiveness;

- Prevention of a social ill-being, making help for citizens, turned up to a hard vital situation;

- Health care (hi-tech treatment for children).

Support of the best social and charity projects ( making a competition among NPO, NPO training, an attraction of specialists of NPO to projects expertise of grant competitions and others). The example can be the company Nizhnekamsk Oil and Chemistry practice, which communicates actively with such non-profit organizations like Public Soviet of Nizhnekamsk municipal district, Nizhnekamsk territorial department of Republic social-political motion of "Tatarstan - the New Age" - "Tatarstan-yanagasir", Nizhnekamsk organization of the Republic social organization "Executive Committee of the World Tatarstan Congress", the Nizhnekamsk branch of the Tatarstan Nations Assembly, the local social organization "Nizhnekamsk Russian Society of Nizhnekamsk" and others.

The SUEK company communicates actively with federal and district NPO in the corporate charity space, including Charity fund "Rusfund", the fund "Give a Life", the Omsk 
regional social organization "The Centre of Social Space Innovations", the regional charity organization "Arkhangelsk Centre of Social Technologies Garant, INO "Pskov Regional Centre of Education Technologies", ANO "The Centre of Social Initiatives Promotion Growth Point" (the city of Leninsk-Kuznetskii) [4]. As the interview showed, for the realization of their external projects companies actively attract volunteers. So, within the program of a corporate volunteering of OMK company, the employees of the companies are given mini-grants for projects realization, directed to specific social problems solution in local towns. Such projects exist in other companies too.

The most developed partnership system has Severstal that communicates with more than 20 partners within social projects realization. Interesting projects with other businesspartners develop SUEK and OMK companies. SUEK company together with LLC TC AIRTIME realize the project "Training movies for financial and economic history of Russia" [5]. OMK company together with SCB Metallinvest made and service the charity-card "OMKParticipation" (the programs of the corporation's charity fund).

The important problem there are risks, connected to the choice of the big number of non-profit organizations, because till the present time there are no certain criterions of NPO professionalism. Wherein it should be considered that in this cooperation every side should find its own interest: NPO- the resource support of its actions and business structure- the organization help in its charity programs realization. According to Ministry of Justice in Russia in the years of 2015-2016 the general number of NPO in Russia stayed stable, with the trending to the certain growth [6]. At the end of 2015 year in its registry were about 226 thousand of NPO, in the December of 2016 the number of NPO was a little bit more than 227 thousand. In the beginning of the November of 2017 year in the Ministry of Justice registry was about 223 thousand registered NPO. As many researches show the number of registered NPO is much more than really working NPO. How not to choose the structure, which doesn't really work? It can be suggested few options to minimize the risk: to resort to the experts help; to interview business partners; to analyze the received application (invitations) for cooperation or to start the search by yourself, orienting to official web-sites of NPO in general as a future partner, including the non-financial accounting.

So here the following problem appears-the lack of developed system of communications and information interchanging between business and NPO. Nowadays the main most available instruments of communication and information sharing between business and NPO are personal meetings, creation and distribution of a social advertising (banners, videos), press releases, publications in mass media, which can make the representatives of the both structures think about important and acutely standing social problems and to resource to the cooperation. But it is not enough.

Nowadays the main source of information interchanging between business and NPO should be their non-financial accounting. In the aim of business transparency growth and
NPO also it is necessary to improve the non-financial accounting quality, which should reflect the real results of financial and non-financial actions of these organizations. Non-financial accountings of commercial companies and non-profit sectors should give an opportunity to inform mutually the representatives of these structures about social and ecological influence on the environment.

Non-financial accountings of SO NPO should be put in a public space (in the official web-site of the organization and in the official web-site of the organization, which gives subsides, in the National Registry of non-financial accountings of the Russian Union of industrialists and entrepreneurs portal (RUIE) [7].

In the condition at the 2 of February of the 2018 year in the National Registry of non-financial accountings RUIE were registered 827 accountings, which were released from the 2000 year. Inside their number there are just 32 accountings, characterizing NPO activities (just 3,9\%), in which are described just the results of charity actions and programs as usual. In some accountings there are no financial results of their activities.

The analysis of a non-financial accounting of commercial structures as corporate documents, which are interested by investors, partners, powerful and controlling department, staff, NPO and territory population, presented in the RUIE web-site, allowed to make following statements. In spite of that NPO are one of the most interested target groups of social accountings of commercial companies, they are not being distinguished as a separate group of stakeholders as usual, don't consider as the specific interests and preferences, there mechanism of communication with them doesn't bring. In this way, full of value information sharing between business and NPO the existed non-financial accounting doesn't provide fully. In this case, companies are suggested to rise the quality of the compiling accountings with the considering of stakeholders' expectations identification and to act with that's conditions.

The actual problem nowadays is still the lack of a continuous investments of NPO activities from commercial structures funds. The proof of this is the data from the Russian Federal State Statistics Department about an allocation of social-oriented non-profit organizations through the sources of money formation funds and another property of an organization from the 2016 year, which showed that admissions from Russian commercial organizations were just $20,9 \%$ from all of the sources of money formation funds. For example, the percentage correlation of corporate donations of the WWF fund is just $10 \%$ of the whole sources of the financing.

Every commercial organization has its own motivation in the solution about financing a non-profit sector- NPO. Among the main problems can be listed the following: a desire to help, the specific values providing, like for example: initiative, novelty, innovative ideas, an entrepreneurial spirit, etc.; the development of the staff's loyalty feeling; the creation of a positive image in society. 
According to the interview made by the High Economy School, 850 NPO from 33 regions of Russian Federation are practically all Russian organizations use corporate fundraising, according to the representative quota selection of organization-legal forms and the years of registration of NPO [8]. In the 2015 year $23 \%$ of NPO took facilities from Russian companies. Today investments of companies are in every ten of NPO.

\section{DISCUSSION}

How to attract business structures to financing charity programs of NPO? In our opinion, firstly the fundraising opportunities should be used. There is no secret that Russian specialists of NPO don't realize all of the fundraising technologies opportunities. What is the barrier for fundraising development in Russia?

- The opacity of charity funds and other NPO activities and a low level of the trust to them in conclusion. A big number of frauds.

- The Lack of fundraising infrastructure development.

- The problem with staff, a lack of professional education in the fundraising area.

In this case it is suggested to do workshops for Russian PR-specialists every year with foreign colleges participation.

\section{CONCLUSION}

In conclusion it is necessary to note that effective cooperation of business and NPO should carry the mutually beneficial character. For the first it brings the rising of stability space of business; the improvement of image and consumers loyalty formation, of the second - the financial and non-financial resources for charity program realization. In General, the development of this cooperation should lead to accelerated sustainable development of Russia.

In our opinion, the main instrument of relationship changing between business structures to NPO activities should become the understanding of the mutually beneficial character and the importance of these relationships, the research of the problems and the reasons of the lack practice of such cooperation. Based on this it is necessary to develop and realize in practice the complex of events for their removal.

The recommendations for the problems removal should connect with questions about risks minimizing, connected with the choice of the partner from a big number of nonprofit organizations by commercial organizations, in conditions of the lack certain criterions of NPO professionalism; about the further system development of communications and information sharing between business and NPO based on the improvement of the non-financial accounting; about calling in business structures to the financing charity programs of NPO based in the maximum using of the available fundraising facilities.

\section{REFERENCES}

[1] M.M. Basova. Analysis of social aspects of a working security and industrial safety in conditions of a stable company development // In the series: Modern problems of administration of environment resources and social-economic system development. Materials of the XII science conference: in 4th, 2016, pp. 33-43.

[2] The official web-site of the World Fund of the Wild Nature ( WWF) [Electronic resource]: https://new.wwf.ru/ (the date of using: 02.02.2018)

[3] The official web-site of the Public ward of Russian Federation. [Electronic resource]:

[4] http://www.oprf.ru/ (the date of using: 04.02.2018)

[5] The official web-site of the incorporated community SUEK. [Electronic resource]

[6] http://www.suek.ru/ (the date of using: 04.02.2018)

[7] The official web-site of Russian Union of industrialists and entrepreneurs.

[8] http://media.rspp.ru/ (the date of using: 01.02.2018)

[9] The official web-site of the Ministry of Justice of Russian Federation [Electronic resource]:http://minjust.ru/ (the date of using: 10.02.2018)

[10] M.M. Basova. The features of non-financial accountings forming in social-oriented non-profit organizations // The Herald of Moscow University in honor of Vitte S.S. Series No.1. Economy and Administration, 2017, № 3 (22), pp. 50-53.

[11] The official web-site of The Centre of Civil Society Researches of a Non-Profit Sector. [Electronic resource]:https://grans.hse.ru/ (the date of using: 10.02.2018) 